\title{
Lord Denning and EEC Law
}

\author{
A. I. L. Campbell*
}

The purpose of this article is to make a general survey of Lord Denning's views and decisions concerning EEC law. It will not assess particular decisions, but will consider his contribution to the reception of and understanding of EEC law.

The impact of Lord Denning's written views in particular has been as striking as his prose. The contribution of Lord Denning seems to have lain partly in his ability to communicate to the profession and to the general public the importance of the legal changes incurred by U.K. entry into the EEC. It has been said that, prior to the entry of the U.K. into the EEC, "the learned journals, and, to some extent, the less learned press, were full of anxiety that the English lawyer and, above, the English judge, would not know how to compete with this new system". ${ }^{1}$ Denning was in a position, as Master of the Rolls, to play a central role in the development of the English reception of EEC law. It is arguably fortunate that a judge such as Denning with a penchant for communication and for an ability to rethink the law, and with a temperament for accepting, not resisting, change, was in this position. After U.K. accession to the EEC Denning was over 70 , having already had a lifetime in acquiring one legal tradition and at an age when resistance to change is strong. It is to Denning's credit that though he may usually have come down on the side of English law where there was an international element, towards the end of his judicial career he faced "realistically" the "incoming tide" of EEC law. ${ }^{2}$ It can be said that he made a deliberate effort to contribute to the understanding and reception of EEC law. He established lasting and influential, if controversial, guidelines on when to refer questions to the European Court, as well as attempting

${ }^{*}$ Lecturer in Law, University of Aberdeen.

The author is grateful to his colleague $\mathrm{Mr}$ P. R. Beaumont and to Mr R. R. Paisley for helpful comments on a draft of this article.

1. Mackenzie Stuart, "The United Kingdom and Community Law - The First Decade", The Third Lord Fletcher Lecture, November 1981, The Lord Fletcher Lectures 1979-1982, Solicitors European Group (1983) p.40. It has to be said, however, that a body of judges (Lords Diplock and Hailsham as well as Denning) anticipated few difficulties with interpreting EEC. Law: see Lasok and Bridge, Law and Institutions of the European Communities 4th ed., p.378, and Bridge, "Community Law and English Courts and Tribunals; General Principles and Preliminary Rulings", 1 European Law Reviesp (1975) 13, at p.18.

2. The Hon Justice Kirby, "Lord Denning: An Antipodean Appreciation", [1986] Denning L.7. 103, at p.110. 
to register the need to adopt different principles from those used in municipal law for the interpretation of EEC law. In addition, he stated interesting views on EEC supremacy. These contributions can be overstated: many of the remarks made by Denning to be examined were in a sense obiter, and they cannot rival his substantive contributions in other areas of the law. But they are interesting, and it could be said that Lord Denning's wish to make such statements beyond the essential needs of the case even reinforces the impression of a judge anxious to communicate the impact of EEC law in general. Denning chose the course of exposition and guidance. Denning wrote at almost a popular level on the general impact of EEC law in the U.K. in The Times in 1973, just after U.K. entry to the EEC, as Master of the Rolls and Chairman of the British Institute of International and Comparative Law. ${ }^{3}$ He showed that he realised that the judiciary must confront new problems - of the conflict between EEC law and domestic law, and of when and how often to refer matters to the European Court of Justice, issues to which he returned on the bench. He also showed perhaps a certain defensiveness, in stating that this new law would be "grafted" on to the old.

An objective to communicate the importance of the change brought about by EEC law was shown vividly in the landmark case of Bulmer v. Bollinger ${ }^{4}$ - the "Champagne" case - in 1974, when he said in a memorably graphic, though perhaps exaggerated, way, that:

"the treaty is like an incoming tide. It flows into the estuaries and up the rivers. It cannot be held back.",

This was described as an "apt analogy", extra judicially, by Lord Fraser, and has also been referred to flatteringly by Lord Scarman as "dazzling", and as a "magificent simile", though not without qualification, by Lord Mackenzie Stuart. In 1978 Lord Denning reinforced the idea:

"the flowing tide of Community law is coming in fast. It has not stopped at high water-mark. It has broken the dykes and the banks. It has submerged the surrounding land. So much so that we must learn to become amphibious if we are to keep our heads above water." 6

Subsequently, Denning was invited to give the first Lord Fletcher lecture, and continued the simile thus:

3 The Times, 2 January 1973.

4 [1974] 2 All E.R. 1226, at p.1231; as to whether it is exaggerated see Mackenzie Stuart, supra n.1, p.38: "If I might continue in the vein of Lord Denning, one might say, however strong may be the currents in the estuary and forceful the incoming tide, these factors do not concern you overmuch if you happen to run a grocery shop in central Scotland."

5 Fraser, "The Impact of Community Law on Scots Law", [19871 Joumal of the Law Society of Scolland 90; Mackenzie Stuart, The European Communities and the Rule of Lam (1977), 1: cf. Mackenzie Stuart, supra n.1, at p.38.

6 Shields v. E. Coomes (Holdings) Lid. [1979] 1 All E.R. 456, at p.462. 
"Now in 1979 the tide is advancing. It is no use our trying to stop it, any more than King Canute did. He got his feet wet; I expect we shall all get our feet wet too."?

The analogy is perhaps to some extent intentionally humorous, but it is not merely amusing, because it communicates to a perhaps conservative profession the need to adjust to the change which the passing of the European Communities Act 1972 had made. This concern was also reflected in Denning's last book on law, What Next in the Law, where he wrote "We should cease to look at [the European Court's] work with English eyes. We should look at it with European eyes . . As I have said before: "The Treaty is like an incoming tide. It flows into the estuaries and up the rivers. It cannot be held back'." 8 Were Lord Denning remembered only for these rather apt similes that might well be worthwhile, since in a simple way they communicate so effectively the inevitable impact of an important new source of law and the extent of the change wrought by this "tide". As we shall see, Lord Denning has more recently expanded these similes. What, however, of Lord Denning's views in more detail? There are three convenient subdivisions of these views: the guidance to courts as to when they should refer to the European Court of Justice for a preliminary ruling under Article 177 of the Treaty of Rome; the question of U.K. Sovereignty; and the interpretation of EEC law.

\section{Preliminary Rulings}

Under article 177 of the Treaty of Rome national courts may, and in some cases must, seek a preliminary ruling on a question as to the interpretation of the treaty from the European Court of Justice. It is well known that guidelines as to when a decision on a question of Community law is necessary and on the exercise of the discretion to refer, accompanied by other remarks on such references, were laid down by Denning M.R. in Bulmer v. Bollinger. ${ }^{9}$ The guidelines on when questions should be referred to the European Court have been influential in the sense of citation at least, even though this might to some extent be a form of lip-service, as a run through on LEXIS shows. Though further important remarks have been made elsewhere ${ }^{10}$ these guidelines remain a commonly quoted starting point for discussion in England, and indeed were cited by Lord Clyde in the first Scottish civil court reference, from the Court of Session. ${ }^{11}$ Kerr LJ with the concurrence of Gibson LJ and Russell LJ has described them, after 13 years, as "a useful list ...

7 "The Incoming Tide", The First Lord Fletcher Lecture, November 1979, The Lord Fletcher Lectures 1979-1982, Solicitors European Group (1983), p.4.

8 (1982), at p.301.

9 [1974] 2 All E.R. 1226, at p.1234.

10 See Bingham $J$ in Commissioners of Customs and Excise v. Samex [1983] 1 All E.R. 1042, at pp.1055-56; R. v. Plymoulh Fustices, Ex parte Rogers [1982] 2 All E.R. 175.

11. Stephen Malcolin Bromn v. Secretan of State for Scolland, unreported but available on LEXIS; $c$. Prince v. Younger [1984] 1 C.M.L.R. 723, at p.727. 
which have stood the test of time." 12 That is not to say that they were exempt from criticism or revision. The guidelines were widely criticised; ${ }^{13}$ they have also not been formally approved by the House of Lords. The extent of detail of the guidelines was arguably unnecessary, and Stephenson LJ in the same case indicated that guidelines should be "few". ${ }^{14}$ But Denning's boldness in laying down such guidelines was possibly very helpful to lower courts, and to the profession, uncertain of European law. Some of the guidelines do have an uncertain status, though this should not allow the general contribution to be overshadowed.

Denning's approach might be, and has been said to be, too restrictive of national courts' discretion to refer, ${ }^{15}$ which is a serious charge in view of the need for uniform jurisprudence on EEC law, as overseen by the European Court itself. A further response to those guidelines on the other hand may be, and has been, that they are too "nationalistic", 16 that is to say that too much discretion is given to national courts to decide on EEC questions themselves. Denning was, for example, anxious that reference to the European Court should not be made unnecessarily, because of the time to get a ruling and the need not to overload the European Court, factors specifically mentioned in Bulmer v. Bollinger and also in the earlier general article in The Times. While this might be said to reflect an unduly conservative attitude, it has practical merit, borne out by the experience of the European Court which now takes even longer than when Denning wrote to

12. R. v. Pharmaceutical Society of Great Britain, Ex parte The Association of Pharnaceutical Importen [1987] 3 C.M.L.R. 951, at p.970.

13. See, e.g., Vaughan (ed.), Law of the European Communities, vol. 1, 1.23, 3.80; Bebr, Development of 7udicial Control of the European Communities, p.377; Lasok and Bridge, Law and Institutions of the European Communities 4th ed., p.378; Collins, European Community Law in the United Kingdom 3rd ed., p.134; Bridge, "Community Law and English Courts and Tribunals; General Principles and Preliminary Rulings", 1 European Law Review (1975) 13; Gormley, "The Application of Community Law in the United Kingdom 1976-1985", 23 Common Market Law Review (1986) 287, at p.289; Brown and Jacobs, The Court of Fustice of the European Communities 2 nd ed., at p.170, and Mitchell and Freeman there cited; Dagtoglou, "The English Judges and European Community Law", [1978] C.L.7. 76; Forman and Stevens, "The Attitude of British Courts to Community Law - The First Three Years", 13 Common Market Lam Reviem (1976) 388, at p.406; see also Encyclopaedia of European Community Lam, vol. B II, under Article 177; Ed. Comment, 1974 Common Market Law Review 349. But, as Parker J. pointed out in Lord Bethel v. SABENA [1983] 3 C.M.L.R. 1, at p.4, they are only guidelines - see also Vaughan (ibid.) and Collins, European Law in the U.K., p.138. Brown and Jacobs say that the guidelines have no legal authority but have had an influence in practice, "emanating from so eminent a source".

14. [1974] 2 All E.R. 1241; Stamp L.J. wholly agreed with Stephenson's judgment.

15. See, e.g., Bebr, Development of Fudicial Control of the European Communities, p.377; Arnull, "Article 177 and the Retreat from Van Duyn", 8 European Law Reviem 365, at p.368 and of. Vaughan I, 1, 23. 16. Usher, in Vaughan (ed.), Law of the European Communities, 3.80; see also Freeman, "References to the European Court of Justice under Article 177", [1975] C.L.P. 176; Forman and Stevens, "The Attitude of British Courts to Community Law", at p.407; Dagtoglou, "The English Judges and European Community Law", at p.89. 
hand down rulings, about fifteen months, and has to handle even more preliminary rulings. ${ }^{17}$

An important issue, however, is that of Acte Clair, much beloved of academics. Denning arguably gave too much scope to this doctrine, possibly out of a general desire not to overload the European Court, and send only cases "worthy of its mettle", ${ }^{18}$ but also possibly because of symptomatic over confidence as to the ease with which the "new law" could be applied by English judges. ${ }^{19}$ Denning accepted the principles of the "previous ruling" and of Acte Clair, the latter being controversial:

"In some cases ... it may be found that the same point - or substantially the same point - has already been decided by the European Court in a previous case. In that event it is not necessary for the English Court to decide it. It can follow the previous decision without troubling the European Court ... In other cases the English court may consider the point is reasonably clear and free from doubt. In that event there is no need to interpret the treaty but only to apply it, and that is the task of the English court."20

These remarks have of course been overtaken by the limited approval of the doctrine of Acte Clair in the European Court judgment in C.I.L.F.I.T.. It recognised that

"the correct application of Community law may be so obvious as to leave no scope for any reasonable doubt as to the manner in which the question raised is to be resolved."

But it qualified this by saying that before the court could come to such a conclusion it

"must be convinced that the matter is equally obvious to the courts of the other Member States and to the Court of Justice."

And it further pointed out difficulties involved in the interpretation of EEC law, such as the different language versions of Community legislation, which are all equally authentic. ${ }^{21}$

17. See H.L. 20, 1987-88, A European Court of First Instance, p.34; this is an increase from 1984 and 1985 - see the Synopsis of the mork of the Court of fistice of the European Communities, Luxembourg, 1986, p.10. In 1972 there were 40 references, in 1985, 139, and in 1987144 requests - H.L. 20, 1987-88, supra, at p.32; Proceedings of the Court of 7 ustice of the European Communities, No. 1/88. It is true, as Forman and Stevens point out ("The attitude of British Courts to Community Law", p.407) that it was no longer true as Denning had stated that the Court could not be split up into divisions, but the recomposition of the Court into Chambers came about because of the growth in the number of references: see The Court of 7ustice of the European Communities (Office for Official Publications, Luxembourg, 1975), at p.14.

18. See The Times, 2 January 1973.

19. See Lasok and Bridge, supra n.l, p.378.

20. [1974] 2 All E.R., at p.1235.

21. [1982] E.C.R. 3415, at p.3430. 
Denning's unqualified adoption of the Acte Clair doctrine also clashes with the cautious approach of the House of Lords in Garland, though that also takes in the "previous ruling" guideline, and indeed may be more relevant to it, where Lord Diplock noted that there was a "question" to justify reference to the European Court since

"there was not ... so considerable and consistent a line of case law of the European Court on the interpretation and direct applicability of art. 119 as would make the answer too obvious and inevitable to be capable of giving rise to what could properly be regarded as 'a question' within the meaning of art. $177 ., 22$

Lord Denning's apparent encouragement of the adoption of the Acte Clair doctrine by national courts on a widespread basis is surely open to reasonable criticism, in allowing the ill considered unilateral interpretation of EEC law. Some balance had to be created between on the one hand preventing unnecessary reference and encouraging a belief that EEC law could be understood and was not wholly alien, and, on the other hand, misconstruing EEC law. An impression that Denning was "in conflict" with the House of Lords cannot be maintained on the basis of two or three cases, especially as Lord Diplock himself described the doctrine of Acte Clair as "common sense", ${ }^{23}$ but perhaps Denning was over confident initially on the possibilities of misconstruction. ${ }^{24}$ Erroneous assumptions can easily be made, as was indeed illustrated, ironically, by Denning's views in the well known case of Schorsch Meier ${ }^{25}$ coupled with the House of Lords' reaction in Miliangos. ${ }^{26}$ The Schorsch Meier case has been taken to illustrate a degree of contentiousness in Denning's guidelines, in emphasising the role of a national court in interpreting EEC law for itself. ${ }^{27}$ Lord Diplock was particularly interested, on the other hand, in expressing caution on a matter being "clear", especially where judicial minds differ, as in Henn and Darby ${ }^{28}$ and in the Gist Brocades cases, ${ }^{29}$ though a disagreement as to whether the law was clear or not, and whether a "comparatively elaborate" finding of Acte Clair was self-contradictory,

22. [1982] 2 All E.R. 402, at p.415.

23. "The Common Market and the Common Law", 6 Law Teacher (1972), p.14.

24. A contrast on initial expectations of judges such as Denning and misconstruction is made by Lasok and Bridge, Law and Institutions of the European Communities, pp.378-379.

25. [1975] 1 All E.R. 152, at p.157.

26. [1975] 3 All E.R. 801, at pp.810-811, 820, 838; "I entertain the strongest reservations concerning the use made by the Court of Appeal of art. 106 in the present context ... Any other court in which such issues may arise would be well advised to refer them to the European Court for clarification"(Wilberforce). See Usher, European Court Practice, 1.69; Freeman, "References to the European Court under Articlc 177", 28 C.L.P. (1975) 176, at p.193; see, however, Denning, The Discipline of Law, p.307.

27. Vaughan (ed.), Law of the European Communities, 3.80; see also Lasok and Bridge, pp.379-80; $c$. Bebr, Development of Fudicial Control, p.378.

28. [1980] 2 All E.R. 166, at p.197.

29. R. v. Compiroller Palents, Exp. Gist Brocades [1986] 1 W.L.R. 51, at p.67. 
became evident in the House of Lords in $\operatorname{Re} S a n d h u .{ }^{30}$ A realisation of the limits of Acte Clair has now become evident in the Court of Appeal too. In R. v.Thomson ${ }^{31}$ Bridge LJ expressly cited the warning of Advocate General Warner that national courts should exercise great caution before considering that the answer to a Community law question admits of no possible doubt. Caution on EEC law was also stated in a way relevant to all questions of interpretation of the Treaty of Rome by Bingham J in Customs and Excise Commissioners v. Samex:

"Sitting as a judge in a national court, asked to decide questions of Community law, I am very conscious of the advantages enjoyed by the Court of Justice."

He drew attention to matters such as the comparison of different texts, detailed knowledge of the treaties and subordinate legislation made under them, and a view of what the orderly development of the Communities requires, where the Court of Justice is much better placed than a national court. ${ }^{32} \mathrm{He}$ also stated in the Bulk Oil case, a week later, that

"The cases show that, even where the English judges have been confident that a point of Community law should be decided in one way, the Court of Justice of the European Communities has not infrequently decided it in the other." 33

These remarks, in Commissioners of Customs and Excise v. Samex, and Bulk Oil, were referred to and approved implicitly by the Court of Appeal in the Bulk Oil case, ${ }^{34}$ and those in Commissioners of Customs and Excise v. Samex were described as "of great relevance" by Kerr LJ in the context of the free movement of pharmaceutical products. ${ }^{35}$ In the Polydor case, ${ }^{36}$ moreover, according to Kerr LJ, "Ormrod and Templeman LJJ expressed strong views in this Court about the apparently clearly correct answer to a question of Community law which had been raised before them. But they nevertheless referred the case to the Court of Justice, and we were told that the ultimate decision was in fact the other way." ${ }^{37}$ Again, Kerr LJ, with the concurrence of his colleagues in the Court of Appeal,

30. The Times, 10 May 1985, available on LEXIS. Lord Fraser found that Lord Templeman's comparatively elaborate analysis indicated that it was not, as Lord Templeman suggested, Acte Clair. Lord Fraser was supported by Lord Brandon but Lord Bridge expressly disagreed on this point.

31. [1980] 2 All E.R. 102, at p.105.

32. [1983] 1 All E.R. 1042, at pp.1055-56.

33. Cited by Ackner LJ [1984] 1 All E.R., at p.391.

34. Bulk Oil A.G. v. Sun Intemational Lid. [1984] 1 All E.R. 386, at p.391.

35. R. v. Pharmaceutical Society of Greal Brilain, Ex parte The Association of Phannaceutical Inporters [1987] 3 C.M.L.R. 951, at p.970.

36. [1980] 2 C.M.L.R. 413.

37. Per Kerr LJ, supra n.35, at p.971. 
emphasised that U.K. courts should "hesitate long" and exercise "great caution" before reaching a conclusion that something is Acte Clair. ${ }^{38}$

These remarks, that national courts should be careful not to assume too readily that they themselves should deal with the matter, must be especially true if they refuse leave to appeal. This happened in the Magnavision Case, ${ }^{39}$ where the Divisional Court stated that the matter before them was clear, though it involved the interpretation of difficult judgments of the European Court itself, and though the Divisional Court considered that one judgment was out of line with the others - and subsequently refused leave to appeal. ${ }^{40}$

The guidelines in Bulmer on the exercise of discretion to refer necessary questions are relevant to courts not bound to refer such questions. Under Article 177 of the Treaty of Rome courts in general may refer questions of interpretation to the European Court, but a court must so refer under Article 177(3) if "there is no judicial remedy under national law" against its decisions. This obligation was also covered by Lord Denning: "short of the House of Lords, no other English court is bound to refer a question ..." That the issue as to which court is bound could be argued about was indicated in the same case, however, where Stephenson LJ expressed doubt on the view that the House of Lords is the only court against whose decisions there is no judicial remedy, ${ }^{42}$ while writers such as Collins have opined that Denning's view was "plainly wrong", ${ }^{43}$ as did Campbell. ${ }^{44}$ There are in fact other more recent cases which indicate that the Court of Appeal is not a 'final court', so that Denning may have been right. Purchas LJ, citing the Bulmer

38. Ibid., at pp.970-71; see also MacPherson J in R. v. H. M. Treasuy, Ex parte Daily Mail and General Trust p.l.c., [1987] 2 C.M.L.R. 1, cited by Kerr LJ, and R. v. Dearlove; R. v. Druker, The Times, 28 January 1988.

39. S. A. Magnavision N.V. v. General Optical Council (No. 2) [1987] 2 C.M.L.R. 262.

40. See analogously, the Bomore case [1986] 1 C.M.L.R. 228, at p.241, though it involved a decision that the question was already covered by the European Court's jurisprudence rather than Acte Clair. 41. [1974] 2 All E.R. 1226, at p.1233; see also The Times, 2 January 1973.

42. At p.1241; Stamp LJ agreed.

43. European Law in the United Kingdom 3rd ed., p.114, writing of course before Pickstone or the Pharmaceutical Society case, referred to in the text: he also cites 8th General Report on the Activities of the European Communities, which stated that Denning's view here "must be treated with reservation"; see also Buckley LJ Hagen v. Fratelli [1980] 3 C.M.L.R. 253, at p.255 indicating that the House of Lords and also the Court of Appeal would be bound to refer if leave to appeal were not obtainable (which is described by Schermers Waelbroeck, Fudicial Protection in the European Commmnities 4th ed., (Kluwer) para.715. as the better solution, but as raising procedural difficulties by Lasok and Bridge, supra n.1, at p.369 n.17), and S. A. Magnavision N.V. v. General Council (No. 2) [1987] 2 C.M.L.R. 262, at pp.265-66, where Watkins LJ considered that if the Divisional Court refuses to certify that there is a point of law for consideration by the House of Lords the Divisional Court may be or was "in a sense" a court of final decision - though no reference to the European Court was made by Watkins LJ and Macpherson J because the matter was considered clear, and because no question was pending or preliminary before the Divisional Court.

44. Common Market Lam Supplement 1975, p.382: "it is respectfully submitted that his view is clearly incorrect". 
guidelines, indicated in Pickstone v. Freemans plc ${ }^{45}$ that the Court of Appeal was not a "final court" under Article 177, and Kerr LJ with the concurrence of his colleagues said in $R$. v. Pharmaceutical Society of Great Britain, ex parte the Association of Pharmaceutical Importers that the Court of Appeal was not a court from which there is no remedy, since there was a possibility of an appeal. ${ }^{46}$ Moreover, the question must be asked whether the Court of Appeal is bound to refer if it has already given judgment, and leave to appeal is refused. ${ }^{47}$ To judge by the Magnavision case the question would no longer be "preliminary", and thus the Court of Appeal would not be bound to refer.

Possibly if the Court of Appeal refuses leave to appeal it should be regarded as a court from which there is no remedy; this is only consistent with justice in the individual case, for which Denning supposedly cared especially, and with the purpose of Article 17 and the case law of the European Court, though there are arguments for an emphasis on 'higher' courts. ${ }^{48}$ It is also arguable that in cases of urgency the Court of Appeal should be regarded as the final court in England, and the view that the House of Lords alone is bound seems inconsistent with Denning's own consideration of the time and expense involved in getting a ruling.

Denning's view had the virtue of clarity, which was also the approach subsequently adopted in the 1968 Convention on Jurisdiction and the Enforcement of Judgments, and 1971 Protocol. It nominated the courts bound to refer questions for a preliminary ruling on interpretation of the Convention and Protocol to the ECJ, and concentrates on the House of Lords. ${ }^{49}$

The matter of the 'final court' under Article 177 is not one in any case on which different views are not possible, and criticism of Denning may be over enthusiastic. Sir Gordon Slynn, an Advocate General, said that it was "clearly" not true that a court "of last resort" means the supreme court, in the U.K. the House of Lords, and that a court from which there is no judicial remedy may be relatively low in the hierarchy, ${ }^{50}$ but Judge Pescatore, a judge of particular authority on the EEC, stated that he preferred the view that a court at the top of the hierarchy is a court from which there is no remedy and that, in any case, the question whether that

45. [1987] 3 All E.R. 756, at pp.770, 776; Oliver LJ found it unnecessary to decide if the decision before him in the Court of Appeal was one from which there is no judicial remedy, so that a reference would be obligatory, in Brilish Leyland Motor Comporation v. Armstrong Patents [1984] 3 C.M.L.R. 102, at p.132 which implies that that decision was arguable.

46. [1987] 3 C.M.L.R. 951, at p.969; the assumption in the Bomore case, [1986] 1 C.M.L.R. 228, at p.241, appears also to have been that the House of Lords was bound to appeal under the last paragraph of Article 177, and the Court of Appeal a discretion to do so.

47. See Usher, European Court Practice, 1.72; Collins, European Community Lam in the United Kingdom, p.113; Lasok and Bridge, Law and Institutions of the European Community, p.376.

48. See Brown and Jacobs, The Court of fustice of the European Communities, pp.167-68; of. Campbell QC, Common Market Law Supplement (1975), p.383, and, on the case law of the Court of Justice, Schermers Waelbroeck, Judicial Protection 4th ed., para. 710.

49. For Schermers Waelbroeck, Fudicial Protection in the European Communities 4th ed. para. 711, the Convention generally follows the "abstract theory", i.e. that concentrating on the highest courts. 50. "The Use of Article 177 of the EEC Treaty", the Fifth Lord Fletcher Lecture 1983, The Lard Fletcher Lectures 1983-1984 1, at p.9. 
court or a court from which there is no appeal in a particular instance is one from which there is no remedy "could give rise to endless discussion." 51 That does suggest that criticism of Denning's view on this issue can get out of proportion. There are of course good reasons for and against both views. ${ }^{52}$

Considering the guidelines as a whole, and the question whether the House of Lords alone is bound to refer, it is clear that they are, or have been, open to criticism. But it would be wrong to over-react. Lord Denning was issuing clear and relatively short guidelines, not writing a statute, and one would expect them to be qualified later. In some respects they echo the previous remarks of Lord Diplock in the need to have regard to time and expense, the need not to overload the European Court, and the acceptance of Acte Clair as "common sense", despite later qualification. ${ }^{53}$ Lord Mackenzie Stuart, the United Kingdom judge on the European Court since our accession and a judge of vast experience, commented:

"It is instructive to look back at some of the specific anxieties expressed at the
beginning of British membership. For example, when should a judge use his
power to refer a case to us? Should the power be exercised only at the level of
the Court of Appeal? For all the academic ink spent in comment on how Lord
Denning's guidelines in Bulmer v. Bollinger [1974] Ch. 401 should be given
effect to, I think the fears have proved groundless. The British judiciary, with
its pragmatic good sense, have referred cases to Luxembourg when they
thought it appropriate having regard to the particular problems raised by the
case before them and, perhaps more importantly, have refused to refer where
domestic law has proved a perfectly adequate solution."

That comment, plus that of Kerr LJ, puts criticism of the guidelines in some perspective. The word "pragmatic" is interesting; perhaps a balance must be struck between freedom to refer and an academic insistence on reference wherever EEC law is alleged to be relevant, the resolution of which balance in particular cases will be open to criticism. As Walton J once pointed out, the invocation of Article 177 requiring, apparently, the court not to enquire into the validity of alleged defences under EEC law, should be treated with circumspection. It should not have an effect even greater than the murmuring of

51. Court of Fustice of the European Communities: References for preliminay rulings under Article 177 of the EEC Treaty and cooperation between the Court and national courts, Office for Official Publications of the European Communities (1986), 16.

52. See Pescatore, ibid.; Bebr, supra n.13, at p.379 ei seq.; Collins, European Community Law in the United Kingdom, p.112; Schermers Waelbroeck, fudicial Protectioan in the European Communities 4th ed., paras. 709-710, suggesting that the obiter in the Costa case was not necessarily meant to settle this matter, though preferring the view that the subsequent case law of the European Court confirms the "concrete theory", which would cover more than the House of Lords.

53. "The Common Market and the Common Law", 6 Law Teacher (1972), pp.13-14. In one respect Lord Diplock was more restrictive, in suggesting that Courts below the Court of Appeal normally

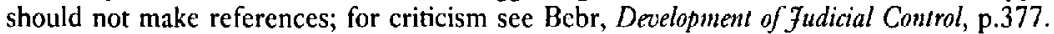

54. "The United Kingdom and Community Law - The First Decade", p.43; see also Collins, supra n.13, at p.140, pointing out that English Courts have not hesitated from seeking guidance from the European Court. Lord Mackenzie Stuart has been succeeded by Sir Gordon Slynn. 
the magic word "Basingstoke" - though unfortunately unwillingness to refer questions to the European Court in that and other similar cases on intellectual property has been open to criticism. ${ }^{55}$

\section{The sovereignty of the U.K.}

Lord Denning was apparently more alive to the supremacy of EEC law than other senior judges, at least on the basis of written judgments. Of course, before U.K. entry to the EEC the question of sovereignty had arisen in Blackburn v. Att.-Gen. ${ }^{56}$ Lord Denning's view there indicated that he was aware that there soon could be a successful challenge to the dogmatic and traditional view of sovereignty of Dicey:

"We have all been brought up to believe that, in legal theory, one Parliament cannot bind another and that no Act is irreversible. But legal theory does not always march alongside political reality ... Legal theory must give way to practical politics ... What are the realities here? If ... Parliament enacts provisions to implement [the Treaty], I do not envisage that Parliament would afterwards go back on it ... If Parliament should do so, then I say we will consider that event when it happens. We will then say whether Parliament can lawfully do it or not."

As Forman and Stevens suggest, Denning did not perhaps need to address himself to the broad question of sovereignty, as well as that of review of the Crown's treaty making power, but it had been raised, and all three judges considered the question; in doing so he was making one of the few general judicial statements on the subject and was here, as Forman and Stevens also point out, addressing one of the most entrenched doctrines in English law. ${ }^{57}$ It is both a conservative and an open minded statement. It is conservative because, despite the statement of a preparedness to rethink the theory of Parliamentary Sovereignty Denning was apparently still beginning from a starting point of traditional terms, of one Parliament not being able to bind another. That indicates that he did not yet accept fully the views of the European Court on supremacy, by which this country is bound, as a pro-European lawyer would do. It was open minded in being prepared to address political realities, and to rethink theory. ${ }^{58}$ Despite his statement that he would consider the problem of withdrawal from the EEC when it happened, he did address that question later, in Macarthys, to an extent that he has

55. British Leyland Motor Copporation v. T.I. Silencers L./d. [1980] 1 C.M.L.R. 598, at p.610 and see also Sir Robert Megarry in I.C.I. v. Berk Pharnaceutical Lid. [1981] 2 C.M.L.R. 91, at p.98; sce, however, British Leyland v. T.I. Silencers Lid. [1980] 2 C.M.L.R., at p.332, [1981] 2 C.M.L.R. 75, and Arnull, supra n.15, at pp. 371-77.

56. [1971] 2 All E.R. 1380, at pp.1382-83; it was cited in the House of Lords when debating the European Communities Bill 1972 by Lords Beswick, Hailsham and Shackleton: H.L. Deb. 7 August 1972, cols. 902, 912; 8 August col. 1048; H.C. Deb. 7 March 1972, col. 1332.

57. Supra n.13, at p.391.

58. The other two judges also made non-committal statements on the subject; Denning's is the statement which made an impact. 
been said to have "escaped from the apparent shackles of orthodox theory". 59 The contrast between traditional theory and reality was echoed later, in considering the impact of the Single European Act. Again he contrasted traditional theory and political reality, and although he did not in terms rethink general theory on the basis of the new political realities, these were in his mind as he declared that Parliamentary Sovereignty had ended.

An overview of Denning's views on Parliamentary Sovereignty and EEC Supremacy suggests that, though there was some inconsistency, he did particularly accept EEC supremacy, as long as there was no express statutory repudiation. This will be considered below. A limited recognition of the supremacy of EEC law underlay The Times article, where he was clearly prepared to say in general that if there was a conflict between a previous Act and the treaty the treaty will "prevail". ${ }^{0}$ This however does not raise the question of sovereignty, since he refers to a previous Act of Parliament and might even be taken to imply that EEC law does not prevail in the case of a later Act of Parliament.

The question of the extent to which EEC supremacy is given effect may arise where a post-1972 statute is enacted in terms different from or inconsistent with prior directly applicable EEC law, and hence inconsistently with the 1972 Act. On standard views of parliamentary sovereignty the effect given to EEC law by the European Communities Act 1972 may be limited by a subsequent statute; no Parliament, including the 1972 one, can limit a subsequent Parliament. The situation is complicated by sections 2(4) and 3 of the European Communities Act 1972. Section 2(4) of the European Communities Act 1972 says - to paraphrase it - that present and future legislation is to be construed and have effect subject to section 2(1), allowing EEC law which is intended to be directly enforceable to be so; section 3 refers to judgments of the European Communities Act 1972, which brings in the doctrine of the supremacy of EEC law stated by the European Court. Both sections of course are themselves open to express or implied repeal. The question is, if there is an inconsistency between EEC law and a later U.K. statute, must the former EEC law prevail, or should the later inconsistent statute be given effect to, or can the two be reconciled? Given the impact of section 2(4) the question is, how far can reconciliation go? This problem was mentioned by Lord Diplock in Garland. In that case he said that it was not then an appropriate occasion to consider whether, in the absence of an express statement in a statute of an intention to be in breach of EEC law, it would be justifiable to construe a statute inconsistently with EEC law "however wide a departure from the prima facie meaning of the language of the provision might be needed in order to achieve

59. Allan, "Parliamentary Sovereignty: Lord Denning's Dexterous Revolution", 31 Oxford foumal of Legal Studies (1983) 22, at p.30, considering the 'self embracing' and 'continuing' schools of theory; $f$. Macarthys [1979] 3 All E.R. 325.

60. The Times, 2 January 1973. 
consistency" ${ }^{61}$ The problem of applying section 2(4) was also clear in Pickstone, ${ }^{62}$ in the Court of Appeal, where Nicholls LJ noted, citing Garland, that there was nothing in the Equal Pay Act 1970 "which expressly or impliedly negatives, or purports to negative, any such Community rights." Of course, it can be argued that there can be no implied limitation or repeal of the 1972 Act unless there is not only an inconsistency between a later statute and EEC law but also between stated provisions in the statute and stated provisions of the European Communities Act $1972,{ }^{63}$ but this seems to be an unduly narrow approach which does not refer to the general and basic question of the intention of Parliament in the later statute, ${ }^{64}$ assuming that the draftsman was aware of EEC law and the $1972 \mathrm{Act}^{65}$ Since the effect of EEC law depends on that Act, the real question must be whether Parliament intends to limit the effect of EEC law, and by implication, the effect of the 1972 Act. The main question, however, is the relationship of EEC law and a statute subsequent to it, as addressed in Garland. ${ }^{66}$

In the main Denning expressed a definite emphasis on EEC supremacy, bringing into clear perspective the existence of that doctrine. In Shields v. E. Coomes (Holdings) Ltd. ${ }^{67}$ he devoted a large part of his judgment to explaining the impact of EEC law - including its supremacy. He remarked that if there were any inconsistency between EEC law and a statute then Community law "prevails", 68 and that the direct applicability and supremacy of EEC law showed that "the flowing tide of Community law is coming in fast ... It has submerged the surrounding land." ${ }^{69}$ Here Denning corrected the misleading impression given by himself (perhaps ex tempore) in Felixstowe Dock and Railway Co and European Ferries v. British Railways Board, where he had said that once the relevant bill became a statute that would dispose of the argument about an abuse of a dominant position under Article 86 of the EEC treaty: "These courts will then have to abide by the

61.[1982] 2 All E.R. 402, at p.415; see also Hood Phillips, "A Garland for their Lords", (1982) 98 L.Q.R. 524 and Allan, "Parliamentary Sovereignty and the EEC", [1982] Public Lam 562.

62. [1987] 3 All E.R. 756, at pp.765-66, 775-76; at the time of writing the House of Lords appeal had not been heard.

63. See Bridge, "Abstract Law and Political Reality in the Post - European - Accession British Constitution", [1987] Denning L.7., 23 at p.36, citing Ellis, "Supremacy of Parliament and European Law", 96 L.Q.R. 511, at p.513; $f$. Usher, in Vaughan (ed.), Law of the European Communities, vol. I, 3.14 .

64. See on implied repeal, Halsbury 4th ed. vol. 44, pp.962, 966; Bennion, Statuton Interpretation, section 180; Maxwell, Interpretation of Statutes 12th ed., (1969), p.187; Craies, Stalute Law 7th ed. (1971), p.366.

65. Diplock and Denning seemed to assume it is knowledge.

66. [1982[ 2 All E.R., at p.415.

67. [1979] 1 All E.R. 456.

68. At p. 46 .

69. [1979] 1 All E.R. 456, at pp.461-62; of. Macarliys v. Smith [1981] 1 All E.R. 111, at p.120 ("Community law is now part of our law; and whenever there is any inconsistency Community law has priority"); and Denning in Garden Cotlage Foods v. M.M.B. [1982] 3 All E.R. 292, at p.294. Too much should not be read into phrases such as "equal in force to any statute", as in Application des Gaz v. Falks Vertitas [1974] 3 All E.R. 51, at p.56 - but see Dagtoglou, stupra n.13, at p.80. 
Statute without regard to the Treaty at all."; ${ }^{70}$ Denning probably did not think through this throw away statement sufficiently - he later was more careful in his remarks.

Where there is an express repudiation of EEC law Denning's attitude was different. In Macarthys v. Smith he returned to the issue of supremacy:

"I have assumed that Parliament, whenever it passes legislation, intends to fulfil its obligations under the Treaty. If the time should come when our Parliament deliberately passes an Act with the intention of repudiating the Treaty or any provision in it or intentionally of acting inconsistently with it and says so in express terms then I should have thought that it would be the duty of our courts to follow the statute ... Unless there is such an intentional and express repudiation of the Treaty, it is our duty to give priority to the Treaty."71

Thus, when Parliament expressly says that it repudiates, by statute, EEC law, or expressly says that it intends to act inconsistently with it, effect must be given to that repudiation, but that unless that happens we must go by EEC law. The phrase "says so in express terms" is not entirely clear; it may mean that the terms of the statute evince such a deliberate intention ${ }^{72}$ or, more probably, that an express or formal statement is made as to intention. ${ }^{73}$

Either interpretation may to some extent be supported by reference to the First Lord Fletcher Lecture $1979,{ }^{74}$ where Denning stated that he had said in a recent case (Macarthys) that "our own Parliament in the last resort, if it so intends, can over-ride Community law. It can, for instance, say that our courts are not to follow Community law on any particular topics. It could in the last resort withdraw." Saying in a statute that our courts are not to follow Community law on a topic would seem sufficiently, in Denning's terms in Macarthys, to "say so" in express terms. If Denning simply meant that a deliberate intention be clear, that the statement mentioned is a "for instance" and the question is if Parliament "so

70. [1976] 2 C.M.L.R. 655 , at pp. 664-65.

71. [1979] 3 All E.R. 325, at p.329.

72. See Collins, European Community Law in the Uniled Kingdom, p.29; $f$. Bridge, op.cit. supra n.63, 1987 Denning L.7. 23, at pp.35-36; Lasok and Bridge, Law and Institutions of the European Communities 4th ed., p.375.

73. See Allan, 31 Oxford Fourmal of Legal Studies (1983) 22, at pp.25-27, who takes it that Denning's requirement of express words mirrors section 2 of the Canadian Bill of Rights 1960. "Every law of Canada shall, unless it is expressly declared by an Act of the Parliament of Canada that it shall operate notwithstanding the Canadian Bill of Rights, be so construed and applied as not to abrogate, abridge or infringe, or to authorize the abrogation, abridgement or infringement af any of the rights or freedoms herein recognized and declared", and (p.31) that it requires that Parliament state expressly that Community law is not to prevail; Wade and Phillips, Constitutional and Administrative Law, p.138, use the words "expressly declare that it prevailed". Lord Fraser, "The Impact of Community Law on Scots Law", [1987] Joumal of the Law Society of Scotland, p.91, cites Macarthys in connection with an Act "clearly stating that it superseded some provision of Community legislation"; $\delta$. Bridge, Lasok and Bridge, supra n.72.

74. At p.8. 
intends", he would be, it is submitted, in conformity with general philosophy on implied repeal. ${ }^{75}$ However in the Lord Fletcher lecture he seems to envisage a specific reference to Community law, ${ }^{76}$ not just a repugnancy, where EEC law and the statute cannot stand together. 'The significance of Denning's statement in Macarthys, according to Allan, is that section 2(4) of the 1972 Act has been to some extent entrenched, that a requirement of form (of express wording) has been placed on any statute designed to override Community law, and the court has departed from the ordinary rule on implied repeal. ${ }^{77}$

As it stands, Denning's statement places more emphasis on express terms than did Lord Diplock in Garland. Lord Diplock anticipated when debating the European Communities Bill that conflicts between statutes and EEC law would not be deliberate, but might arise by accident or oversight, that there were a great many cases where statutes were ambiguous; but that if Parliament decided (unambiguously) to amend or repeal directly applicable EEC law then the courts would be bound to give effect to the subsequent statute; he seems to have contemplated express repeal or amendment, rather than the academic possibility of implied repeal as such. ${ }^{78}$ But he also suggested extra judicially, before the enactment of section 2(4), that, generally, the courts would give effect to a statute where there was a conflict between a subsequent statute and EEC law. ${ }^{79}$ The Diplock statement in Garland, and that of Nicholls LJ in Pickstone do also leave open the possibility of implied repeal of EEC law without an express statement. ${ }^{80}$ Of course in Macarthys Denning may simply have been taking the clear case, particularly because he was concerned with the extreme possibility of withdrawal from the U.K., even if he meant that an express statement be made, ${ }^{81}$ and it seems clear from the Lord Fletcher lecture that he was focussing on the clear, extreme, cases of 'the last resort'.

The apparent requirement of an express statement appears to echo clause 3 of Lord Wade's Bill of 1977 (not long before Macarthy's), a Bill to give effect to the European Convention on Human Rights, which stated that in the case of a conflict between a subsequent statute and the European Convention, the Convention should prevail unless the statute "explicitly" said otherwise. ${ }^{82}$ It also echoes the 75. For rules on implied repeal see n.64 supra.

76. Cf. Allan, supra n.73, who interpreted Macarhys in this way.

77. Ibid., at pp.25, 32. As Bridge puts it, supra n.72, at p.24, "the eponym who graces this fourral has been credited with accomplishing a 'dexterous revolution!"'

78. H.L. Deb, 8 August 1972, cols.1028-1029, and $c$. Lord Hailsham at col. 1051; here Diplock made the interesting statement that "it is difficult to think of any section in an Act of Parliament in which one cannot say there is one meaning or another." Presumably he thought such an approach would normally provide the solution to conflicts. Diplock's statement that "the only problem so long as the Community survives" would in practice arise where there is an oversight or accident was echoed by Denning in Macarhys [1979] 3 All E.R. 325, at p.329.

79. "The Common Market and the Common Law", The Lam Teacher (1972), p.8.

80. See also Bridge, op.cit. supra n.63, p.38.

81. See also the Lord Fletcher Lecture, and What Next in the Law, at p.300.

82. See H.L. 176, 1977-78, Report of the Select Committee on a Bill of Rights, Annex.; $f$. Allan, supra $n$.73. The Committee (p.36) wished to amend it to read as regards later Acts "unless it provides otherwise or does not admit of any construction compatible with this Act", which is wider. 
statement of Sir Geoffrey Howe, who spoke for the government as SolicitorGeneral in the Second Reading Debates on the 1972 Act, that he did not go so far as Lord Diplock's statement (extra-judicially) that any later statutes plainly in conflict with our obligations under the treaties would be given effect to, but endorsed the proposition "that a subsequent United Kingdom statute - even if not designed to pull us out of the Communities - which began with the phrase 'notwithstanding the provisions of Clause 2 ... of the European Communities Bill, black shall be white' would mean that the courts of this country would give effect to that limited proposition, certainly as the matter now stands"; of course he seems to be taking the clear case. ${ }^{83}$ It is again consistent with suggestions that statutes of constitutional importance are not necessarily subject to implied repeal to the same extent as ordinary statutes. ${ }^{84}$ Any emphasis on the need for an express statement is practical because it becomes relatively clear when EEC law is not to be given effect to, i.e. when there is an express, stated intention so to do within the statute. ${ }^{85}$ Denning was later to complain that section $2(4)$ is obscure and unintelligible. $^{86}$

Denning's was in any case an early and clear statement of the position where there is a conflict between EEC law and a statute, indicating that he was alive to that problem. It is interesting that the word "priority" is used by Denning - a word reflecting the question of supremacy which is implicit in section 3 of the $1972 \mathrm{Act}$, rather than the straightforward one of construction as under the terms of section 2(4) of the 1972 Act.

Lawton LJ in the same case, preferred to emphasise the operation of the 1972 Act, remarking, after citing sections 2(1) and 2(4) of that Act, that there was nothing in the statute concerned - the Equal Pay Act 1970 as amended by the Sex Discrimination Act 1975 - to indicate an intention to amend or to limit the application of the European Communities Act 1972, "indicate" being less formal, apparently, than Denning's words "says so in express terms". 87

83. "The European Communities Act 1972", 49 International Affair (1973) 1, at p.9, citing 838 H.C. Deb. 13 June 1972, col. 1320, where he said that "most people" agreed that a statute with a phrase as in the text would be given effect to; a proposed requirement that section 2(4) provide for Parliament saying "notwithstanding our obligations the following shall take effect", or "unless the contrary' appears", was rejected by Howe as providing in advance for the breach of treaty obligations; see also Viscount Colville of Culross, H.L. Debates 8 August 1972, col. 1024. Sir Geoffrey Howe considered the possibility also of an inadvertent conflict, when the courts would "try" to construe the statute in accordance with our international conventions: ibid., at col. 1321. Viscount Colville stated that the advice that had been given was that if there were unavoidable conflict the courts would have to give effect to the statute: H.L. Deb. 8 August 1972, cols. 1024, 1027.

84. See Halsbury 44, at p.966 (citing Lord Wilberforce in Petition of Earl of Antrim [1967] 1 A.C., at p.724, but also Karapier v. Wijeshina [1968] A.C. 717), and Hailsham's evidence to the Select Committee on a Bill of Rights, H.L. 81, 1977-78, p.16, but see H.L. 176, 1977-78, p.22, n.1.

85. Cf. Halsbury 44, at p.962, Bennion, section 180 on implied repeal generally.

86. The Salisbun Review, April 1987, p.11; see also H.L. Deb. vol. 480, 1986, col. 1090.

87. [1979] 3 All E.R., at p.334. Cf. Usher in Vaughan, I, 3.14. 
Certainly Denning's broad view was partially upheld in the judgment of Lord Diplock in Garland ${ }^{88}$ The implication from that judgment is at least that an express statement would justify construction inconsistently with EEC law. Lord Denning's view has also received support, extra judicially, from Lord Fraser, who stated, citing Macarthys and Garland, that an express positive statement in a statute of an intention to overrule or depart from a piece of Community legislation would be given effect to. ${ }^{89}$

Denning's attitude to the passing of the European Communities (Amendment) Bill, giving effect to the Single European Act, indicates a more traditional personal desire to defend the Sovereignty of Parliament, but also a realistic and perhaps radical recognition of the supremacy of EEC law, which in the views of some may have been an over-reaction. In the House of Lords he vigorously opposed the passing of the Bill, declaring that it would "seriously erode" the sovereignty of the Queen in Parliament, ${ }^{90}$ ranging himself on the side of the "traditional constitutionalists" to ensure the supremacy of Parliament. ${ }^{91}$ Here he was rebuffed. As he himself remarked, The Times' headline was "Denning crushed on sovereignty". ${ }^{92}$ But he returned to the attack at the Committee stage, putting down amendments so as to prevent a repeal or amendment of a statute by an EEC directive, or by a decision of the European Court, so that it would be public. ${ }^{93} \mathrm{He}$ further went into print, in The Salisbury Review, and in The Times. In The Salisbury Reviem $^{94}$ he recognised initially the traditional sovereignty of the Queen in Parliament, ${ }^{95}$ but continued:

"For nearly 300 years our constitutional law has been based on the fundamental principle that Parliament was the supreme legislative authority in and for the United Kingdom. It alone could make or unmake our laws, amend or alter them. That sovereignty has now been ended. Its overthrow will be completed by Parliament itself when it passes the European Communities (Amendment) Bill ... So we have to reckon with a new constitutional principle. Community law, as declared by the European Court of Justice, is superior over any Act of our Parliament which is inconsistent with it." ${ }^{\prime 96}$

88. [1982] 2 All E.R. 402, at p.415; see also Hood Phillips, "A Garland for their I.ords", 98 L.Q.R. (1982) 524, and Allen, "Parliamentary Sovereignty and the EEC", [1982] Public Lam 562.

89. "The Impact of Community Law on Scots Law", [1987] Joumal of the Lan Sociely of Scotland 90, at pp.91-92.

90. H.L. Deb. 1986, vol. 479, col. 1056. See also his account in The Salisbury Reviem, April 1987, 8 at p.12, and H.L. Deb. vol. 480, cols. 1089-90.

91. See The Salisbury Review, April 1987, p.12.

92. Ibid., at p.12.

93. H.L. Deb, 1986, vol. 480, col. 1090; cf. The Salisbur Reviem, April 1987, p.12.

94. "The Single European Act", ibid., p.8.

95. Ibid., at p.11.

96. Ibid., at pp.11-12. 
Equally his article in The Times, headed with the dramatic by-line "Farewell to our Sovereignty" stressed in the same way that Parliamentary Sovereignty had ended. ${ }^{97}$

It must be said that Denning's views seem to be dictated by his reaction to the Single European Act. That Act made changes to the Treaty of Rome and was given effect to in the U.K. by the European Communities (Amendment) Act, which he mentions: in his view the Bill was not confined to economic matters but covered legal and political matters as well. His views were also influenced by considerations as to the role of the European Court, which has declared the supremacy of Community law. ${ }^{98}$ His reaction to the single European Act itself was controversial. Indeed attempts to reopen the question of sovereignty on the Single European Act were, generally, dismissed by Bridge as misconceived. ${ }^{99}$

Denning did accept and support the changes made once the European Communities (Amendment) Bill became an Act. ${ }^{1}$ Thus he wrote in his usual graphic style:

"Let us give the Single European Act our wholehearted support. Long ago, when we entered the Common Market, I drew this picture:

'The Treaty is like an incoming tide...'

Now I continue the imagery:

Look, there is a ship coming in with the tide. She is called European Union. But she is in difficulty ... Send out a good boat to help her. Here is one. It is called the United Kingdom. Put good men aboard the European Union."2

However, Denning's later reaction to the EEC commission's suit against the United Kingdom on failure to implement an EEC directive on V.A.T. contrast with those views on the loss of sovereignty. This suit concerned the zero-rating of items, which it was alleged was not proper under the Directive. In an article in The Times Denning argued that:

"The zero-rating case is of immense constitutional significance ... I am quite sure that, when we entered the European Community, no one ever thought that we were giving the European Court of Justice power to declare invalid our Acts of Parliament, especially those dealing with taxation, on which we have always felt most strongly ... the people of England . . . will condemn the

97. The Times, 3 November 1986, p. 20 .

98. See H.L. Deb. vol. 479, 1986, 1056-59; The Salisbury Review, supra n.90, at pp.8, 10. Denning also thought it possible that European courts of first instance would sit in England.

99. "Abstract Law and Political Reality in the Post-European-Accession British Constitution", [1987] Denning L.7., 23, at p.41.

1. He was reported as saying that "he had shed his wig and gown for a politican's robe": The Times, 4 November 1986.

2. The Salisbury Review, supra n.90, at p.13; see also The Times, supra n.97. 
Commission for bringing those proceedings challenging the sovereignty of our Parliament." 3

The article is subject to some criticism, for example in the complaint that the U.K. Parliament and not its government should have been sued, overlooking the fact that the Commission sues Member States, represented in this case by the government. ${ }^{4}$ The main point is, however, that Denning was here, on a temporary issue, again prepared to defend the sovereignty of Parliament.

To sum up, Denning's views on sovercignty are not entirely consistent. But they are indicative of a lawyer prepared to think for himself, and to address the issue of sovereignty squarely. For a lawyer brought up on Dicey these views are radical, and his views after he retired from the Bench especially in The Salisbury Revien are both provocative and progressive.

\section{Interpretation of the law}

In Bulmer v. Bollinger Lord Denning had some comments to make on the interpretation of EEC law. These comments were not revolutionary and have been duplicated since, but they remain an early clear statement of the need to interpret EEC law in a different way:

"it is apparent that in very many cases the English courts will interpret the treaty themselves. They will not refer the question to the European Court at Luxembourg. What then are the principles of interpretation to be applied? Beyond doubt the English courts must follow the same principles as the European Court ... They must follow the European pattern. No longer must they examine the words in meticulous detail ... They must look to the purpose or intent ... They must not confine themselves to the English text. They must consider, if need be, all the authentic texts ... If they find a gap, they must fill it as best they can." 5

Over a page of the All England Report is taken up with this advice. This was surely much needed, and because it was stated at such an early stage may well have been influential. It was perhaps made in response to a realisation of the difficulties which the profession faced in adjusting to the law. Probably such advice was given with some pleasure by a judge noted for his preference for reasoning in any case by

3. The Times, 22 July 1987; see also H.L. Deb. 1986, vol. 480, col. 1090; The Salisbury Review, supra n.91.

4. See letter to The Times, 27 July 1987 by Langdon - Davies for that, and other criticisms. He is correct in saying that the E.C.J. does not declare Acts to be "invalid", but Denning might say that that is the effect. See also letters in The Times, 29 July 1987.

5. [1974] 2 All E.R. 1226, at pp.1236-37. Cf. Application des Gaz v. Falks Verilas [1974] 3 All E.R. 51, at pp.56-57; Schorsch Meier [1975] 1 All E.R. 152, at p.157; see also The Discipline of Lam (1979), p.17. The appropriate principles of interpretation to interpret the EEC Treaty were also addressed by L.ord Diplock in Henn and Darby [1980] 2 All E.R. 166, at p.196. 
"principle". 6 This is perhaps suggested by his judgment in 7ames Buchanan, 7 where he related his participation in a discussion in Luxembourg with members of the European Court, and other colleagues of the member states. He articulated the "European method" on interpretation, the purposive approach, and urged its adoption on European matters, before continuing: "Even in interpreting our own legislation, we should do well to throw aside our traditional approach and adopt a more liberal attitude." It has rightly been said that Viscount Dilhorne's cool response to the suggestion that "gaps" in legislation could thus be filled, that our membership of the EEC does not entail abandonment of traditional methods of interpretation, was unduly dismissive. ${ }^{9}$ At the same time there was perhaps insufficient stress by Denning on the linguistic difficulties faced by an English judge in interpretation, difficulties drawn attention to by Lord Mackenzie Stuart, and by the European Court in C.I.L.F.I.T., and by Bingham J subsequently, ${ }^{10}$ though he did refer to the other authentic texts in Bulmer, and considered, but would not go by, the French text of a directive in Phonogram v. Lane. ${ }^{11}$ It is arguable of course that the differences in approach to interpretation of English law and EEC law or international conventions are exaggerated. ${ }^{12}$ But the Renton Committee on The Preparation of Legislation expressly cited Denning's remarks on interpretation in Bulmer, having written that there are differences in drafting technique in England and Europe, ${ }^{13}$ and Denning himself thought it particularly important to emphasise the attractiveness of the "European" method:

6. See also Bridge, op. cit., n.l at p.17, on Denning's creative outlook.

7. [1977] 1 All E.R., at pp.522-23.

8. He referred here in James Buchanan to an old battle over interpretation, when advocacy of a 'purposive' approach to interpretation of statutes was condemned in the House of Lords by Lord Simonds: see Denning The Discipline of Lam, p.13; Bridge, op. cil, 17. The response to Lord Denning's remarks from the House of Lords in James Buchanan was not enthusiastic: [1977] 3 All E.R. 1053, at p.1056. See also The Discipline of Lam, p.22.

9. Lasok, in Vaughan (ed.), Law of the European Communities, vol. I, 1.47.

10. C.I.L.F.I.T. [1982] E.C.R., at p.3430; Bingham J in Commissioners of Customs and Excise v. Samex [1983] 1 All E.R. 1042, at pp.1055-56.; Mackenzie Stuart, The European Communities and the Rule of Law (1977), p.72.

11. [1981] 3 All E.R. 182, at p.186.

12. See Lord Wilberforce in James Buchanan v. Babco [1977] 3 All E.R., at p.1053: "the assumed and often repeated generalisation that English methods are narrow, technical, and literal, whereas continental methods are broad, generous and sensible, seems to me insecure at least as regards interpretation of international conventions"; see also Collins, European Community Law in the United Kingdom, p.96; Dagtoglou, "The English Judges and European Community Law", at pp.77-78; and Pescatore, Court of Justice of the European Communities: Information for lanyers, Office for Official Publications of the European Communities (1984), p.29: "the Court's methods of interpretration ... do not differ in principle from methods applied by any court ... but their liberal inspiration is worth recording. The court operates in the framework of a completely new legal system which still presents gaps and discontinuities in many respects. Under these circumstances it has to make constructive use of the methods of legal interpretation ..." Cf. Viscount Dilhorne in James Buchanan, at p.1056; Vaughan (ed.), Law of the European Communities, vol. I, 1.47; Lasok and Bridge, Law and Institutions of the European Communities, p.87.

13. Cmnd 6053, 1975, pp.51, 146; Denning was happy to cite this report in James Buchanan. 
"I would now pass on to our most important task. It is the interpretation of statutes and treaties. If you read this Treaty, if you read the regulations and directives under it, they are all part of our law. How different they are from ours ... The European Court ... have what they call a method of interpretation called the 'teleological' or 'schematic' method ... It is very different altogether from our English method of interpretation. I hope that the European method of interpretation will pervade ours ... But I am a lone voice in this." 14

Denning's judgments also contain advice as to the substantive content and impact of EEC law, again going beyond perhaps what was strictly necessary for the decision of the case before him. Thus in Re Westinghouse Electric Corporation Uranium Contract Litigation MDL Docket No. 235 (No. 2), he drew attention, in what he called a "digression", to the EEC Commission's powers of investigation and to the contrast with traditional English law:

"In making an investigation, the European Commission is armed with great powers given by EEC Council Regulation 17/62, arts. 11 to 20. This will come as a surprise to those of us who have been brought up in the common law." 15

About a page of the law report is taken up with an exposition of the powers of the Commission.

Denning also spent some time in Shields v. Coomes $^{16}$ explaining the doctrine of direct applicability, one of the two "twin pillars", he said, of EEC law, in an apparent attempt to enunciate a general perspective of the new legal order. Here again about a page and a half is taken up with explaining the new legal order. However Denning was open to criticism in not making it sufficiently clear early on that not all of EEC law is directly applicable, and in broad brush statements that the treaty is "part of our law", apparently giving the impression that all of the Treaty's provisions are, whereas he may have meant that no further Parliamentary intervention was required for them to have effect. In 1973 he had said in The Times $^{17}$ that "There are several international conventions which have been incorporated into our law by Act of Parliament and our courts have not the slightest reluctance in applying them. They do so because Parliament has so enacted. They will do the same with the Treaty of Rome and the regulations. So, far from rejecting it, they will incorporate it into the body of our law." In an early case, Application des Gaz v. Falks Veritas, ${ }^{18}$ he said:

14. 'The Incoming Tide', op.cit., at p.12.

15. [1977] 3 All E.R. 717, at p.722.

16. [1979] 1 All E.R. 456 , at p.461

17. 2 January 1973.

18. [1974] 3 All E.R. 51, at pp.55-56. 
“... the European Communities Act 1972 ... said that the Treaty of Rome was to be given legal effect in the United Kingdom . . . the treaty is part of our law. It is equal in force to any statute. It must be applied by our courts."

That broad emphasis on the effect of the Treaty of Rome is misleading, in the sense that it could be inferred that all of the treaty has similar effect. That inference could be corrected, since he then considered separately the question of a remedy, with the implication that the effect in a particular case was a distinct question, and went on to point out that, according to the jurisprudence of the European Court, Article 85 creates rights which can be enforced directly. ${ }^{19}$ In the Trendtex case Denning again referred to the Treaty as simply "part of the law of England". ${ }^{20}$ This may have been intended to communicate the legal relevance of the Treaty in an English court - or its potential relevance - in contrast to the normal rule as to treaties. But to say that the "treaty is part of our law", unqualified, may suggest that all its provisions are applicable directly, and the strong word "heresy" has been levelled at the suggestion that all treaty provisions are part of the law of England and enforceable by its courts. ${ }^{21}$ In Bulmer he had indeed declared that "any" rights or obligations created by the treaty are under section 2(1) to be given effect "without further ado", which suggests again that he was thinking of incorporation, but is less undiscriminating, though he also said, broadly, Parliament had decreed the treaty to be "part of our law".22

In Schorsch Meier ${ }^{23}$ he stated that the treaty was part of English law, observing that it creates rights and obligations not only between member states but also between member states and citizens, and between citizens (citing the European Van Gend en Loos case), suggesting his discrimination between the different effect of the treaty provisions. But he said in respect of Article 106 that he was applying the Treaty of Rome in an English court for the first time, which showed its "great effect", having brought about a "fundamental change". ${ }^{24}$ This may suggest an uncritical approach to the different effect of provisions of the treaty, as in Miliangos Lord Wilberforce seriously doubted whether Article 106, in question, is directly applicable. ${ }^{25}$

In Re Westinghouse Electric Corporation Uranium Contract Litigation MDL Docket No. $235,{ }^{26}$ Denning further remarked that:

19. At p.58.

20. [1977] 1 All E.R. 881, at p.892.

21. Lasok and Bridge, Law and Institutions of the European Communities 4th ed., p.376.

22. [1974] 2 All E.R., at pp.1231-32.

23. [1975] 1 All E.R. 152, at pp.157-58.

24. Ibid., at p.158.

25. [1975] 3 All E.R., at p.810; see also Lasok and Bridge, supra n.21, at p.379; Bridge, op. cit. n.18, at 20; Usher, European Court Practice, 1.69.

26. [1977] 3 All E.R. at 703, at p.711. In James Buchanan v. Babco [1977] 1 All E.R. 518, at p.523, he said that "In interpreting the Treaty of Rome (which is part of our law) we must certainly adopt the new approach" (emphasis added). See also Macarthys v. Smith [1981] 1 All E.R. 111, at p.120; Garden Coltage Foods v. M.M.B. [1982] 3 All E.R. 292, at p.294; The First Lord Fletcher Lecture (1979), p.12. 
"The EEC Treaty and all its provisions are now part of the law of England: that is clear from s. 2 of the European Communities Act 1972. We have to give effect the treaty as being incorporated, lock, stock and barrel, into our own law here."

By virtue of the section 2 mentioned, in fact, only certain EEC rights intended to be given effect to without further enactment shall be enforced accordingly. In this sense, as Collins put it, the treaty is not incorporated "lock, stock and barrel", ${ }^{27}$ and the phrase "and all its provisions" was in itself also misleading; the context was Article 85, which Denning had decided, on the basis of a decision of the ECJ, to have direct enforceability in Application des Gaz v. Falks Veritas, ${ }^{28}$ and regulation $17 / 62$, which as he said, ${ }^{29}$ is directly applicable. Perhaps he was intending to emphasise in general the important fact that provisions of the Treaty of Rome may be enforced in English courts, and are not "alien law", whereas normally of course treaties and treaty provisions are not part of English law, which the context of his remarks ("incorporated") does suggest. The point of the "lock, stock and barrel" statement may have been that no further Parliamentary intervention is required for the Treaty provisions to have effect. But that is perhaps open to question also, in the sense that Community law is not in its entirety incorporated. Sir Geoffrey Howe, who was in charge of the Second Reading of the 1972 Bill, wrote of the terms of section 2(1): "Community law . . has not been incorporated into or made identical with our own domestic law. Our courts are simply required to give direct effect to Community law according to its own nature, "in accordance with the Treaties ... I do not accept in its entirety the phrase 'as part of the law of the United Kingdom' [in the 1967 White Paper]. Community law retains its own nature."30

Denning did make it clear that not all of the Treaty is directly applicable in Shields v. E. Coomes (Holdings) $L t d{ }^{31}$ where, after remarking that "all the rights and obligations arising under the treaty are to be given legal effect", he explained the doctrine of direct applicability in some detail:

"any citizen ... can require his own courts to enforce his Treaty rights. It is not every article which permits of 'direct applicability'. It is only those articles which are sufficiently clear, precise and unconditional as not to require any further measure of implementation."

27. Collins, supra n.13, at p.35; see also Lasok and Bridge, Law and Institutions of the European Communities, p.376, and Bridge, supra n.1, pp.14-15.

28. [1974] 3 All E.R. 51, at p.58.

29. [1977] 3 All E.R., at p.712.

30. "The European Communities Act 1972", 49 International Affairs (1973) 1, at pp.4-5.

31. [1979] 1 All E.R. 456, at p.461. When he wrote on the European Act, in 1987, he also did make it clear that "As I read section 2 of the [European Communities] Act, the only provisions of the treaty which are certainly binding in England are those which are operative "without further enactment"': The Salisbury Reviem, April 1987, p.11 (and see H.L. Deb. vol. 480, 1986, col. 1089); he was, however, contrasting directives which, he said, were binding after further enactment, whereas the European Court had held that directives can be enforceable in an English court in the Marshall case. 
Yet, when Denning wrote his What Next in the Lam, he wrote that "The Treaty of Rome is part of our law", and "all of the articles of the Treaty and many of its Regulations and Directives are to be enforced directly by the English courts." 32 Again, the assumption in his mind may have been that constitutionally speaking the Treaty was "incorporated". This seems to be suggested by the context of the remarks here as well as elsewhere: ${ }^{33}$ "By an Act of Parliament ... the Treaty of Rome is part of our law. Our courts. have to give effect to it just as if it had been passed by our Parliament ... all of the articles ... are to be enforced ... even though we have no legislation upon the point passed by our own Parliament." In 1986, speaking in the House of Lords he similarly stated that, whereas in constitutional law treaties normally are not binding in England, section 2 of the 1972 Act made it clear that "all rights, obligations, or whatever, under the treaty are without further enactment to be given effect or used in the United Kingdom and recognised and available in law. In other words, every right and obligation in that Treaty of Rome was brought into our statute by Parliament by Section 2(1)."34 Yet, in the sense mentioned, these are over-broad statements; the word "all", in both quotations, (or "every"), together with "enforced directly", is misleading. ${ }^{35}$ Again, the "as if it had been passed" is questionable. Sir Geoffrey Howe explained: "Community law retains its own nature. Certainly it will take effect here by virtue of an Act of Parliament. But not 'as if enacted' thereby. The point I wish to underline is the provision that is made for the application within this country of future Community law - that which is 'from time to time provided for by or under the treaties'."36

So, to conclude on interpretation of the law, Lord Denning's judgments and writings are typically vigorous and informative, pointing out the need for different attitudes on EEC law, and communicating the general impact of EEC law - the principles of interpretation, the investigations by the EEC Commission, and the principles of supremacy and direct applicability. On section 2, however, there have to be reservations about, at least, his expression of the effect of the European Communities Act 1972, because perhaps he wished to emphasise the general constitutional point of the relationship of treaties to U.K. law. Perhaps, leaving Schorsch Meier aside, it can be said that these failures of expression were not serious, but if Denning's purpose was to communicate the dramatic impact of EEC law, he arguably over emphasised it here, and left himself open to criticism, especially when his remarks in What Next in the Lam are considered.

32. (1982), pp.293, 295; 'emphasis added'.

33. Ibid., at p.294; in The Salisbury Reviem, at p.11; H.L. Deb., 1986, vol. 480, col. 1089, he drew attention to the words "without further enactment" but he was concerned partly to contrast the effect of directives. Article 189, he thought, envisaged further enactment.

34. H.L. Deb. vol. 480, 1986, col. 1060.

35. The context was the European Communities (Amendment) Bill.

36. "The European Communities Act 1972", supra n.30, at p.5. 


\section{Conclusion}

In general conclusion any judgment on Denning's contribution in the field of EEC law must seem presumptuous. Some of his contributions are open to criticism. The general impression, however, is of a vigorous and lasting contribution to a communication of the impact of EEC law, even if it was marred in the loose phraseology on the effect of the Treaty of Rome and EEC law. There was a contribution too in the establishment of guidelines on the reference of questions of EEC law to the European Court, and in interesting, even radical, but inconsistent thoughts on Sovereignty. 